\title{
Kewenangan Notaris Dalam Pembuatan Akta Risalah Lelang Pasca Berlakunya Peraturan Menteri Keuangan Nomor 90/PMK.06/2016 Tentang Pedoman Pelaksanaan Lelang Dengan Penawaran Secara Tertulis Tanpa Kehadiran Peserta Lelang Melaui Internet
}

\author{
Tomy Indra Sasongko \\ tomyindra08@yahoo.co.id
}

\begin{abstract}
Law on Notary (UUJN) regulates a notary in his authority to be able to make an auction minutes deed. Currently, auctions can be performed via the internet without the presence of bidders. This research discussed, first, the practice of notary's authority and responsibility as a class II auction official in an auction and, second, the implementation of internet auction conducted by the Directorate General of State Assets of the Ministry of Finance of the Republic of Indonesia. This study was normative legal research that examined the regulations or legal rules as a system related to legal cases in practice. The results showed that, first, the notary is authorized to make the deed of auction minutes but this cannot apply directly without the appointment from the Ministry of Finance. The legal power of the minutes of auction through the internet remains the same as that of a conventional auction. Second, in the Regulation of the Minister of Finance concerning the implementation of auction through the internet or conventional auction, it is mentioned that the minutes of auction for an official report is an authentic deed and has the power of perfect proof of evidence. The rules and implementation of the making of minutes of auction through the internet are the same as those for conventional auctions.
\end{abstract}

Keywords: Notary authority; auction minutes deed; internet auction

\begin{abstract}
Abstrak
UUJN mengatur notaris dalam kewenangannya untuk dapat membuat akta risalah lelang. Pelaksanaan lelang saat ini dapat dilaksanakan melalui internet tanpa kehadiran peserta lelang. Penelitian ini mengangkat permasalahan, pertama, bagaimana pelaksanaan wewenang dan tanggungjawab notaris dalam pelaksanaan lelang sebagai pejabat lelang kelas II? Kedua, bagaimana pelaksanaan lelang melalui internet yang dilaksanakan oleh Kementerian Keuangan Republik Indonesia Direktorat Jenderal Kekayaan Negara di Indonesia? Penelitian ini adalah penelitian hukum normatif yaitu meneliti kaidah atau aturan hukum sebagai bangunan sistem yang terkait dengan peristiwa hukum yang terjadi dalam praktik. Hasil penelitian menunjukkan bahwa pertama, notaris berwenang membuat akta risalah lelang namun tidak dapat diterapkan secara langsung tanpa adanya pengangkatan dari Kementerian Keuangan. Kekuatan hukum Risalah Lelang melalui internet tetap sama seperti kekuatan hukum pada lelang konvensional. Kedua, pada Peraturan Menteri Keuangan pelaksanaan melalui internet maupun dengan pelaksanaan lelang secara konvensional menyebutkan Risalah Lelang suatu berita acara yang merupakan akta otentik dan mempunyai kekuatan pembuktian sempurna. Peraturan dan pelaksanaan dalam membuat akta risalah lelang melalui internet sama seperti lelang secara konvensional.
\end{abstract}

Kata-kata Kunci: Kewenangan notaris; akta risalah lelang; pelaksanaan lelang melalui internet 


\section{Pendahuluan}

Lelang merupakan mekanisme jual-beli dengan melakukan pengumuman atas penawaran barang sebagai objek lelang secara terbuka kepada calon peserta lelang pada saat yang bersamaan. Kemudian pada hari yang telah ditentukan, lelang dilaksanakan dimana pada saat itu para peserta lelang saling menawar harga dari barang sebagai objek lelang tersebut dengan penawaran harga yang semakin mendekati harga yang diinginkan penjual atau pemilik barang. Apabila harga telah tercapai atau tidak ada peserta lain yang menawar dengan harga yang lebih tinggi, maka diputuskan seorang pemenang lelang, dan akan terjadi jual beli secara lelang antara penjual/pemilik barang dengan pemenang lelang sebagai pembeli.

Pengertian lelang dapat kita temukan dalam Peraturan Menteri Keuangan Nomor 27/PMK.06/2016 tentang Petunjuk Pelaksanaan Lelang BAB 1 Ketentuan Umum Pasal 1 ayat (1), "Lelang adalah penjualan barang yang terbuka untuk umum dengan penawaran harga secara tertulis dan/atau lisan yang semakin meningkat atau menurun untuk mencapai harga tertinggi, yang didahului dengan Pengumuman Lelang". Pada peraturan tersebut Pasal 2 juga memaparkan bahwa, dalam hal ini setiap pelaksanaan lelang harus dilakukan oleh dan/atau dihadapan Pejabat Lelang kecuali ditentukan lain oleh Undang-Undang atau Peraturan Pemerintah.

Berdasarkan uraian di atas dapat dikatakan bahwa lelang adalah suatu bentuk penjualan barang yang dilakukan secara terbuka untuk umum dengan harga penawaran yang semakin meningkat atau menurun untuk mencapai harga tertinggi, yang diajukan secara tertulis maupun secara lisan, sebelumnya didahului pemberitahuan tentang akan adanya pelelangan atau penjualan barang. ${ }^{1}$

Pada Pasal 1 angka 1 Undang-Undang Nomor 2 Tahun 2014 tentang Pengganti Undang-Undang Nomor 32 Tahun 2004 tentang Jabatan Notaris (UUJN) yang menyebutkan Notaris adalah Pejabat Umum yang berwenang untuk membuat akta otentik dan kewenangan lainya sebagaimana dimaksud dalam Pasal

${ }^{1}$ Rachmadi Usman, Hukum Lelang, Sinar Grafika Offset, Jakarta, 2016, hlm. 21 
15 UUJN. Kedudukan Notaris sebagai Pejabat Umum, dalam arti kewenangan yang ada pada Notaris tidak pernah diberikan kepada pejabat-pejabat lain dalam membuat akta otentik dan kewenangan lainya, maka kewenangan tersebut menjadi kewenangan Notaris. ${ }^{2}$

Berdasarkan Pasal 15 ayat (1) UUJN Notaris berwenang membuat akta autentik, Akta Notaris merupakan akta autentik yang dibuat oleh atau di hadapan Notaris menurut bentuk dan tata cara yang ditetapkan dalam Undang-Undang Jabatan Notaris. Sedangkan akta otentik menurut Pasal 1868 KUHPerdata menerangkan bahwa suatu akta autentik ialah suatu akta yang didalam bentuk yang ditentukan oleh undang-undang, dibuat oleh atau dihadapan pegawaipegawai umum yang berkuasa untuk itu di tempat dimana akta dibuatnya.

Akta otentik mempunyai pembuktian yang sempurna. Kesempurnaan akta Notaris sebagai alat bukti, maka akta tersebut harus dilihat apa adanya, tidak perlu dinilai atau ditafsirkan lain, selain yang ditulis dalam akta tersebut. ${ }^{3}$

Kesempurnaan akta autentik juga tertuang didalam KUHPerdata Pasal 1870 yang menyatakan :

Bagi para pihak yang berkepentingan beserta par ahli warisnya ataupun bagi orang-orang yang mendapatkan hak dari mereka, suatu akta otentik memberikan suatu bukti yang sempurna tentang apa yang termuat di dalamnya. (KUHPerdata 1875). Dari peraturan tersebut bahwa akta autentik merupakan suatu akta yang pembuktianya sempurna.

Dalam kewenangan Notaris juga di sebutkan pada UUJN Pasal 15 ayat (2) dimana Notaris berwenang di antaranya pada huruf g menyatakan bahwa Notaris berwenang untuk membuat Akta Risalah lelang. Peraturan tersebut memberikan keleluasaan atas wewenang Notaris dalam melaksanakan jabatanya sebagai Pejabat Umum dimana Notaris dapat pembuatan Akta Risalah lelang.

Akta risalah lelang merupakan suatu berita acara yang dibuat oleh pejabat lelang yang merupakan akta outentik dan mempunyai kekuatan pembuktian sempurna. Di sini peran notaris terhadap wewenang yang telah tercantum dalam UUJN merupakan bagian dari notaris membuat akta tersebut.

\footnotetext{
${ }^{2}$ Ibid., hlm. 40

${ }^{3}$ Habib Adjie, Hukum Notaris Indonesia, PT. Refika Aditama, Bandung, 2008, hlm. 121
} 
Pelayanan penyelenggaraan lelang dapat dilakukan oleh pihak swasta melalui Balai Lelang berdasarkan Keputusan Menteri Keuangan nomor 47/KMK.01/1996 tentang Balai Lelang, yang disempurnakan beberapa kali, terakhir dengan Peraturan Menteri Keuangan Nomor 118/PMK.07/2005 tentang Balai Lelang, kemudian dicabut dan diganti dengan Peraturan Menteri Keuangan Nomor 176/PMK.06/2010 tentang Balai Lelang sebagaimana diubah dengan Peraturan Peraturan Menteri Keuangan Nomor 160/PMK.06/2013. Dari ketentuan tersebut, pihak swasta nasional maupun swasta asing, termasuk Badan Usaha Milik Negara (Daerah) diberikan kesempatan yang sama untuk dapat melakukan kegiatan usaha di bidang lelang melalui Badan Lelang, yang berbentuk Perseroan Terbatas. ${ }^{4}$ Kemudian Pada 19 Februari 2016 peraturan mengenai petunjuk pelaksanaan lelang melahirkan peraturan baru yaitu Peraturan Menteri Keuangan Nomor 27/PMK.06/2016 tentang Petunjuk Pelaksanaan Lelang. Pada Pasal 99 PMK 27/PMK.06/2016 sebagai ketentuan penutup yang menyatakan bahwa :

"Pada saat Peraturan Menteri ini mulai berlaku, Peraturan Menteri Keuangan Nomor 93/PMK.06/2010 tentang Petunjuk Pelaksanaan Lelang sebagaimana telah diubah dengan Peraturan Menteri Keuangan Nomor 106/PMK.06/2013, dicabut dan dinyatakan tidak berlaku."

Pada dasarnya setiap pelaksanaan lelang harus dilakukan oleh dan/atau di hadapan Pejabat Lelang, kecuali ditentukan lain oleh undang-undang atau peraturan pemerintah. Keharusan atau kewajiban pelaksanaan dilakukan oleh dan/atau di hadapan Pejabat Lelang ini dipertegas lain dalam Pasal 2 Peraturan Menteri Keuangan Nomor 27/PMK.06/2016, yang menyatakan bahwa "Setiap pelaksanaan lelang harus dilakukan oleh dan/atau di hadapan Pejabat Lelang, kecuali ditentukan lain oleh Undang-Undang atau Peraturan Pemerintah."

Berdasarkan ketentuan di atas, setiap pelaksanaan lelang wajib dilakukan oleh dan/atau di hadapan Pejabat Lelang, kecuali ditentukan lain oleh undangundang atau peraturan pemerintah yang menyatakan bahwa. Pelaksanaan lelang dapat dilakukan tanpa campur tangan Pejabat Lelang. Artinya penjualan objek

${ }^{4}$ Rachmadi Usman, Op. Cit., hlm. 12 
lelang harus dilakukan oleh dan/atau di hadapan Pejabat Lelang, dengan ketentuan sepanjang tidak ditentukan lain atau ada pengecualian. ${ }^{5}$

Menurut Pasal 1 angka 14 Peraturan Menteri Keuangan Nomor 27/PMK.06/2016, yang dimaksud Pejabat Lelang yaitu orang yang berdasarkan peraturan perundang-undangan diberi wewenang khusus untuk melaksanaan penjualan barang secara lelang. Dalam hal tersebut maka dapat diartikan bahwa suatu Pejabat Lelang adalah seseorang yang di tunjuk wewenang khusus oleh Menteri Keuangan Untuk melaksanakan penjualan suatu barang secara lelang yang sudah ditentukan oleh peraturan perundang-undangan.

Ketentuan mengenai Pejabat Lelang kelas II masih di atur dan disempurnakan dalam Peraturan Menteri Keuangan Nomor 159/PMK.06/2013 tentang Perubahan atas Peraturan Menteri Keuangan Nomor 175/PMK.06/2010 tentang Pejabat Lelang Kelas II. Dalam hal ini Pejabat Lelang Kelas II di angkat oleh Direktur Jendral Kekayaan Negara atas nama Menteri Keuangan, syarat menjadi Pejabat Lelang Kelas II salah satunya wajib Lulus pendidikan dan pelatihan yang diselenggarakan oleh Direktur Jendral Kekayaan Negara.

Kewenangan, kewajiban dan larangan dari Pejabat Lelang kelas II dapat dilihat dalam Pasal 12 sampai dengan Pasal 15 Peraturan Menteri Keuangan Nomor 175/PMK.06/2010 sebagaimana telah diubah dengan Peraturan Menteri Keuangan Nomor 159/PMK.06/2013. Peraturan tersebut menjelaskan bahwa kewajiban Pejabat Lelang Kelas II diantaranya membuat minuta Risalah Lelang dan menyimpannya sesuai peraturan perundang-undangan tidak hanya itu Pejabat Lelang Kelas II juga berkewajiban untuk membuat salinan Risalah Lelang, Kutipan Risalah Lelang, dan Grosse Risalah Lelang sesuai peraturan perundang-undangan.

Kewenangan Notaris yang diatur pada UUJN pada Pasal 15 ayat (2) huruf g mengenai Notaris berwenang dalam membuat Akta Risalah Lelang maka peran Notaris dalam membuat akta Risalah lelang sangat dimungkinkan untuk menjalankan wewenang tersebut sebagai pejabat umum untuk memberikan pelayanan atas peraturan yang telah di atur dalam UUJN. Notaris dalam hal ini dapat menjalankan kewajiban dari Pejabat Lelang Kelas II tanpa dilantik oleh DJKN.

${ }^{5}$ Ibid., hlm. 32 
Tidak hanya itu didalam Peraturan Menteri Keuangan Nomor 27/PMK.06/2016 bagian kedua penawaran lelang pada Pasal 64 ayat (3) juga mengatur lelang secara online, pasal tersebut menyatakan bahwa penawaran lelang secara tertulis tanpa kehadiran Peserta Lelang dilakukan:

a. melalui surat elektronik (email)

b. melalui surat tromol pos; atau

c. melalui internet baik cara terbuka (open bidding) maupun cara tertutup (closed bidding)

Secara khusus di dalam Peraturan Menteri Keuangan Nomor 90/PMK.06/2016 tentang Pedoman Pelaksanaan Lelang dengan Penawaran Secara Tertulis Tanpa Kehadiran Peserta Lelang melalui Internet pada Ketentuan Umum Pasal 1 ayat (1) menyebutkan bahwa Lelang Dengan Penawaran Secara Tertulis Tanpa Kehadiran Peserta Lelang Melalui Internet, yang selanjutnya disebut Lelang Melalui Internet, adalah penjualan barang yang terbuka untuk umum dengan penawaran harga secara tertulis tanpa kehadiran peserta lelang untuk mencapai harga tertinggi, yang dilakukan melalui aplikasi lelang berbasis internet.

\section{Rumusan Masalah}

Rumusan masalah dalam penelitian ini adalah: pertama, bagaimana pelaksanaan wewenang dan tanggungjawab notaris dalam pelaksanaan lelang sebagai pejabat lelang kelas II? Kedua, bagaimana pelaksanaan lelang melalui internet yang dilaksanakan oleh Kementerian Keuangan Republik Indonesia Direktorat Jenderal Kekayaan Negara di Indonesia?

\section{Tujuan Penelitian}

Pertama, untuk menganalisis pelaksanaan wewenang dan tanggungjawab notaris dalam pelaksanaan lelang sebagai pejabat lelang kelas II. Kedua, untuk menganalisis pelaksanaan lelang melalui internet yang dilaksanakan oleh Kementerian Keuangan Republik Indonesia Direktorat Jenderal Kekayaan Negara di Indonesia. 


\section{Metode Penelitian}

Jenis penelitian yang dilakukan adalah penelitian hukum normatif yaitu meneliti kaidah atau aturan hukum sebagai bangunan sistem yang terkait dengan peristiwa hukum. Penelitian hukum normatif dilakukan dengan maksud untuk memberikan argumentasi hukum sebagai dasar penentu apakah sesuatu peristiwa sudah benar atau salah serta bagaimana sebaiknya peristiwa itu menurut hukum. ${ }^{6}$ Metode penelitian hukum ini berusaha menemukan aturan atau norma serta teori hukum untuk menjawab isu hukum yang tercantum dalam rumusan masalah. ${ }^{7}$

Penelitian normatif dilakukan dengan cara meneliti bahan hukum yang merupakan bahan hukum primer atau disebut penelitian kepustakaan mengenai kewenangan notaris yang dapat membuat akta risalah lelang yang berkaitan dengan pelaksanaan lelang melalui internet. Bahan hukum primer yang akan dilihat dan dianalisis adalah kewenangan notaris dalam membuat akta risalah dengan pelaksanaan lelalng melalui internet, aturan-aturan mengenai kewenangan notaris dalam pembuatan akta risalah lelang sehingga akan didapatkan kesimpulan mengenai bagaimana kewenangan notaris dalam pembuatan akta risalah lelang pasca berlakunya peraturan pelaksanaan lelang melalui internet.

\section{Hasil Penelitian dan Pembahasan}

Kewenangan Notaris dan Implementasi Notaris dalam membuat akta risalah lelang menurut Undang-Undang Nomor 2 Tahun 2014 tentang Perubahan Atas Undang-Undang Nomor 30 Tahun 2004 tentang Jabatan Notaris.

Kewenangan Notaris dalam membuat akta risalah lelang menurut UndangUndang Nomor 2 Tahun 2014 tentang Perubahan Atas Undang-Undang Nomor 30 Tahun 2004 tentang Jabatan Notaris.

Dalam Pasal 1 angka 1 UUJN, Notaris didefinisikan sebagai pejabat umum yang berwenang untuk membuat akta otentik dan kewenangan lainya sebagaimana dimaksud dalam UUJN. Definisi yang diberikan oleh UUJN ini merujuk pada tugas dan wewenang yang dijalankan oleh notaris. Artinya notaris

\footnotetext{
${ }^{6}$ Mukti Fajar dan Yulianto Ahmad, Dualisme Penelitian Hukum, Normatif dan Empiris, Pustaka Prima, Yogyakarta,2015, hlm. 36. 56.

${ }^{7}$ Peter Mahmud Marzuki, Penelitian Hukum, Edisi Revisi, Cetakan ke-9, Kencana, Jakarta, 2014, hlm. 42-
} 
memiliki tugas sebagai pejabat umum dan memiliki wewenang untuk membuat akta otentik serta kewenangan lainya yang diatur oleh UUJN. ${ }^{8}$

Terminologi berwenang (bevoegd) dalam PJN dan UUJN diperlukan karena berhubungan dengan ketentuan Pasal 1868 KUHPerdata yang menyatakan bahwa suatu akta otentik adalah yang sedemikian, yang dibuat dalam bentuk yang ditentukan oleh undang-undang atau dihadapan pejabat umum yang berwenang untuk itu, ditempat akta itu dibuat. Untuk pelaksanaan Pasal 1868 KUHPerdata tersebut pembuat undang-undang harus membuat peraturan perundangundangan untuk menunjuk para pejabat umum yang berwenang untuk membuat akta otentik dan oleh karena itulah para notaris ditunjuk sebagi pejabat yang sedemikian berdasarkan PJN maupun UUJN. ${ }^{9}$

Pengertian notaris sebagai pejabat umum satu-satunya yang berwenang membuat akta dalam rumusan PJN tidak lagi digunakan dalam UUJN. Penggunaan kata satu-satunya (uitsluitend) dimaksudkan untuk memberikan penegasan bahwa notaris adalah salah-satunya yang mempunyai wewenang umum itu, tidak turut pejabat lainya. Semua pejabat lainya hanya mempunyai wewenang tertentu yang artinya wewenang mereka tidak meliputi lebih dari pada pembuatan akta otentik yang secara tegas ditugaskan kepada mereka oleh undang-undang. Perkataan uitsluiting dengan dihubungkan dengan bagian kalimat terakhir PJN mempunyai arti dengan mengecualikan setiap orang lain (met uitsluiting van ider ander). Dengan perkataan lain, wewenang notaris bersifat umum sedangkan wewenang para pejabat lainya adalah pengecualian. Itulah sebabnya bahwa apabila di dalam peraturan perundangundangan untuk suatu perbuatan hukum diharuskan adanya akta otentik maka hal itu hanya dapat dilakukan dengan suatu akta notaris, terkecuali peraturan perundang-undangan ada yang menyatakan dengan tegas bahwa selain dari notaris juga pejabat umum lainya turut berwenang atau sebagai yang satu-satunya berwenang untuk itu. ${ }^{10}$ Dalam hal demikian berlaku asas lex specialis derogate legi

8 Abdul Ghofur Anshori, Lembaga Kenotariatan Indonesia Perpektif Hukum dan Etika, Tim UII Press, Yogyakarta, 2009, hlm. 13-14

${ }^{9}$ G.H.S Lumban Tobing, Peraturan Jabatan Notaris, Erlangga, Jakarta, 1983, hlm. 33

${ }^{10}$ Ibid., hlm. 34. 
generali yakni notaris sebagai pejabat yang berwenang untuk membuat akta pengecualian ini dengan didasarkan pada peraturan perundang-undangan (khusus) lainya. ${ }^{11}$

Terminologi satu-satunya (uitsluitend) dalam UUJN tidak lagi dicantumkan. Meskipun demikian pengartian notaris tidak berubah secara radikal. Hal ini dikarenakan terminologi uitsluitend telah tercakup dalam penjelasan UUJN yang menyatakan bahwa notaris adalah pejabat umum yang berwenang untuk membuat akta otentik sejauh pembuatan akta otentik tertentu tidak dikhususkan bagi pejabat umum lainya. ${ }^{12}$

Kewenangan notaris, menurut Pasal 15 UUJN adalah pembuatan akta otentik mengenai perubahan, perjanjian dan ketetapan yang diharuskan oleh peraturan perundang-undangan dan/atau yang dikehendaki oleh yang berkenpentingan untuk dinyatakan dalam akta otentik, menjamin kepastian tanggal pembuatan akta, penyimpanan akta, memberikan grosse, salinan, dan kutipan akta, semuanya itu sepanjang pembuatan akta-akta itu tidak juga ditugaskan atau dikecualikan kepada pejabat lain atau orang lain yang ditetapkan oleh undang-undang.

Melalui pengertian notaris tersebut terlihat bahwa tugas seorang notaris adalah menjadi pejabat umum, sedangkan wewenangnya adalah membuat akta otentik. Sedangkan akta otentik adalah suatu akta yang bentuknya ditentukan oleh undang-undang, dibuat oleh atau dihadapan pegawai-pegawai umum yang berkuasa untuk itu di tempat dimana akta dibuatnya. Akta notaris sebagai akta otentik dibuat menurut bentuk dan tata cara yang ditentukan oleh UUJN. ${ }^{13}$ Rumusan UUJN dan PJN menyatakan bahwa notaris adalah pejabat umum (openbaar ambtenaar). Seseorang menjadi pejabat umum, apabila ia diangkat dan diberhentikan oleh pemerintah dan diberi wewenang dan kewajiban untuk melayani publik dalam hal-hal tertentu. ${ }^{14}$

\footnotetext{
11 Abdul Ghofur Anshori, Op. Cit., hlm. 15

12 Loc. Cit

${ }^{13}$ Ibid., hlm. 16

${ }^{14}$ Ibid
} 


\section{Implementasi Notaris dalam Membuat Akta Risalah Lelang}

Setiap melakukan suatu tindakan notaris wajib mematuhi aturan yang sudah ditentukan, tindakan yang harus dilakukan notaris sesuai dengan aturan yang berlaku mengenai wewenang notaris. Dalam Pasal 15 ayat (1) juga menerangkan bahwa:

Notaris berwenang membuat akta otentik mengenai semua perbuatan, perjanjian, dan ketetapan yang diharuskan oleh peraturan perundangundangan dan/ atau yang dikehendaki oleh yang berkepentingan untuk menyatakan dinyatakan dalam akta otentik, menjamin kepastian tanggal pembuatan akta, memberikan grosse, salinan dan kutipan akta, semuanya itu sepanjang pembuatan akta-akta itu tidak juga ditegaskan atau dikecualikan kepada pejabat lain atau orang lain yang ditetapkan oleh undang-undang.

Namun dalam rumusan Pasal 15 ayat (2) huruf g ini menimbulkan multipenafsiran, dan penafsiran terhadap pasal ini menimbulkan adanya dua pandangan tentang arti dalam kewenangan Notaris berkaitan dengan akta risalah lelang yaitu: ${ }^{15}$

a. Pertama, setiap Notaris secara serta merta berwenang untuk membuat akta risalah lelang artinya jabatan Notaris dengan jabatan pejabat lelang disatukan, begitu menjadi Notaris otomatis ia menjalankan pekerjaan-pekerjaan pejabat lelang. Dengan demikian jika seorang sudah diangkat menjadi Notaris ia tidak perlu diangkat menjadi pejabat lelang.

b. Kedua, tidak semua Notaris mempunyai wewenang untuk membuat akta risalah lelang walaupun Nptaris dan pejabat lelang mempunyai kualifikasi yang sama sebagai pejabat umum, hanya Notaris yang telah disahkan dan ditetapkan sebagai pejabat lelang kelas II yang berwenang untuk membuat akta risalah lelang.

Memperhatikan adanya dua pendapat yang berbeda sebagaimana terurai di atas, dalam memahami suatu arti Pasal 15 ayat (2) huruf g UUJN tidaklah hanya dipahami dengan membaca secara harfiah kata-kata dalam Pasal tersebut, tetapi Pasal 15 ayat (2) huruf g UUJN itu harus dipahami sebagai suatu sistem yang tidak dipisahkan dengan pasal-pasal, penjelasan pasal-pasal dan penjelasan umum dari UUJN, maupun dengan hukum nasional secara keseluruhan. Untuk memahami

${ }^{15}$ Sjaifurrachman \& Habib Ajie, Aspek Pertanggungjawaban Notaris dalam Pembuatan Akta, CV. Mandar Maju, Bandung, 2011, hlm. 85 
arti Pasal 15 ayat (2) huruf g UUJN maka haruslah dihubungkan dengan Pasal 35 Peraturan Lelang (Vendu reglement) Stb. 1908 No. 189 Jo Stb. 1940 No. 59 dan Pasal 7 Intruksi Lelang (Vendu instructive) Stb. 1908 No. 190, beserta Peraturan Pelaksanaanya seperti Peraturan Menteri Keuangan Republik Indonesia Nomor 27/PMK.06/2016 tentang Petunjuk Pelaksanaan Lelang. Undang-Undang Jabatan Notaris telah memberikan perluasan kewenangan kepada Notaris dalam menjalankan jabatanya sebagaimana tercantum dalam Pasal 15 UUJN, salah satu kewenangan Notaris yang disebutkan dalam UUJN adalah kewenangan Notaris untuk membuat akta risalah lelang. ${ }^{16}$

Untuk dapat menjadi Pejabat Lelang Kelas II terdapat syarat yang harus di peroleh dan dilaksanakan, tidak terkecuali pada Notaris. Salah satunya pada Peraturan Menteri Keuangan Nomor 175/PMK.06/2010 tentang Pejabat Lelang Kelas II Pasal 2 berisi mengenai Pejabat Lelang Kelas II diangkat dan diberhentikan oleh Direktur Jendral atas nama Menteri dan harus memenuhi syarat diantaranya lulus pendidikan dan pelatihan untuk Pejabat Lelang Kelas II yang diselenggarakan oleh Badan Pendidikan dan Pelatihan Keuangan Kementrian Keuangan serata telah mengikuti praktik kerja (magang).

Wewenang Notaris untuk membuat akta risalah lelang dalam implementasinya tidak dapat langsung membuat akta risalah lelang karena dalam membuat akta risalah lelang oleh Notaris tidak otomatis Notaris dapat membuat akta risalah lelang, notaris harus dengan pengangkatan oleh Direktorat Jendral Kekayaan Negara dan harus mengikuti pendidikan dan pelatihan yang diselenggarakan oleh Kementrian Keuangan kemudian ada kewajiban untuk magang. Pasal 15 ayat (2) huruf g UUJN tidak secara otomatis dapat di laksanakan, namun harus disertai dengan ketentuan yang berlaku di Kementrian Keuangan. ${ }^{17}$

Dalam ilmu hukum memang terdapat berbagai jenis interpretasi atau penafsiran, salah satu jenis penafsiran yang secara konvensional dikenal dalam ilmu hukum adalah interpretasi sistematik. Substansi interpretasi ini adalah mengedepankan ketentuan yang sama bersama dengan premis-premisnya untuk

${ }_{17}$ Wawancara dengan Notaris-PPAT dan Pejabat Lelang Kelas II Kota Yogyakarta pada hari Kamis tanggal 18 Mei 2017. 
dibuat suatu konklusi, apabila penafsiran ini digunakan, menurut Yusril Ihza Mahendra, maka kata-kata membuat akta risalah lelang sebagaimana terdapat dalam Pasal 15 ayat (2) huruf g UUJN harus dibaca sebagai berikut, kewenangan Notaris sebagai pejabat yang berwenang membuat akta risalah yang merupakan kewenangan pejabat lelang sehingga Notaris juga mempunyai kewenangan sebagai pejabat lelang yang memimpin jalannya suatu pelelangan dan kewenangan lainnya diatur dalam Vendu Reglement. Dengan tegas dikatakan Yusril sebaiknya antara jabatan Notaris dengan jabatan Pejabat lelang disatukan, begitu menjadi Notaris otomatis ia menjalankan pekerjaan-pekerjaan pejabat lelang. Dengan demikian jika seseorang sudah diang menjadi Notaris, ia tidak perlu diangkat menjadi pejabat lelang. ${ }^{18}$

Pernyataan Yusril diatas kiranya berlebihan, karena apabila menggunakan penafsiran sistematis untuk menafsirkan yang terdapat dalam Pasal 15 ayat (2) huruf g UUJN tersebut, harus melihat ketentuan-ketentuan yang terkait dengan risalah lelang sebagai satu kesatuan. Penafsiran atau interpretasi sistematis adalah suatu cara penafsiran undang-undang sebagai bagian dari keseluruhan sistem perundang-undangan dengan jalan menghubungkannya dengan undang-undang lain. ${ }^{19}$ Oleh karena itu untuk menafsirkan ketentuan Pasal 15 ayat (2) hurf g UUJN dengan menggunakan penafsiran sistematis, maka titik utamanya adalah risalah lelang. ${ }^{20}$

Ketentuan Pasal 15 ayat (2) huruf g UUJN mengatur bahwa Notaris berwenang membuat akta risalah lelang. Pengertian risalah lelang tidak ditemukan dalam UUJN tersebut. Jadi yang digunakan adalah pengertian risalah lelang yang terdapat dalam Peraturan Menteri Keuangan Nomor: 27/PMK.06/2016 tentang Petunjuk Pelaksanaan Lelang, dimana disebutkan bahwa risalah lelang adalah berita acara pelaksanaan lelang yang dibuat oleh pejabat lelang yang merupakan akta otentik dan mempunyai kekuatan pembuktian sempurna bagi para pihak. Yang dimaksud dengan pejabat lelang disebutkan dalam Peraturan Menteri

\footnotetext{
18 "Notaris otomatis PPAT", Majalah Renvoi, 03 Februari 2006, hlm. 15

${ }^{19}$ Sudikno Mertokusumo, Mengenal Hukum suatu Pengantar, Liberty, Yogyakarta, 1999, hlm. 157

${ }^{20}$ Sjaifurrachman \& Habib Ajie, Op. Cit., hlm. 89
} 
Keuangan Nomor: 27/PMK.06/2016 adalah orang yang khusus diberi wewenang oleh Menteri Keuangan melaksanakan penjualan barang secara lelang. Menurut Peraturan Menteri tersebut yang berwenang membuat risalah lelang adalah orang yang diangkat oleh Menteri Keuangan. ${ }^{21}$

Dari penjelasan di atas, yang berwenang secara nyata Notaris untuk membuat akta risalah lelang sebagaimana dimaksud dalam Pasal 15 UUJN tidak dapat diterapkan begitu saja. Artinya seorang Notaris tidak dapat serta merta memangku jabatan sebagai pejabat lelang. Hal ini dikarenakan pengangkatan pejabat lelang dilakukan oleh Menteri Keuangan, sedangkan pengangkatan Notaris dilakukan oleh Menteri Hukum dan Hak Asasi Manusia. ${ }^{22}$ UUJN telah memberikan perluasan kewenangan kepada Notaris dalam menjalankan jabatanya sebagai pejabat umum. Salah satunya mengenai kewenangan yang terdapat dalam Pasal 15 ayat (2) huruf $\mathrm{g}$, bahwa Notaris berwenang membuat akta risalah lelang namun peraturan tersebut tidak dapat diterapkan secara langsung tanpa adanya pengangkatan dari Kementrian Keuangan, karena dalam hal ini suatu pelelangan umum yang ditugaskan untuk membuat risalah lelang adalah pejabat lelang yang terdapat dalam peraturan Vendu reglement, maka Notaris yang berwenang untuk membuat akta risalah lelang adalah Notaris yang telah memenuhi persyaratan dan kualifikasi sebagai pejabat lelang serta telah diangkat dan ditetapkan oleh Meneri Keuangan untuk menjalankan jabatannya sebagai pejabat lelang kelas II.

Maksud yang terkandung pada pasal 15 UUJN yaitu, Notaris diberi keleluasaan merangkap jabatan menjadi pejabat lelang. Untuk dapan menjadi pejabat lelang Notaris wajib mengikuti aturan yang dibuat oleh Menteri Keuangan. Dimana notaris yang ingin menjadi pejabat lelang wajib untuk diangkat oleh Direktorat Jendral Kekayaan Negara dan memenuhi semua syarat yang telah ditentukan.23

Kekuatan Hukum Akta Risalah Lelang Pasca Berlakunya Peraturan Menteri Keuangan Nomor 90/PMK.06/2016 tentang Pedoman Pelaksanaan Lelang dengan Penawaran Secara Tertulis Tanpa Kehadiran Peserta Lelang Melalui Internet.

${ }^{23}$ Wawancara dengan Notaris-PPAT dan Pejabat Lelang Kelas II Kota Semarang pada hari Selasa tanggal
} 6 Juni 2017 


\section{Kekuatan Hukum Akta Risalah Lelang Melalui Internet}

Risalah lelang menurut Peraturan Menteri Keuangan Nomor 90/PMK.06/2016 tentang Pedoman Pelaksanaan Lelang dengan Penawaran Secara Tertulis Tanpa Kehadiran Peserta Lelang Melalui Internet adalah berita acara pelaksanaan lelang yang dibuat oleh Pejabat Lelang yang merupakan akta otentik dan mempunyai kekuatan pembuktian sempurna. Sedangkan minuta Risalah Lelang adalah Asli Risalah lelang berikut lampiranya, yang merupakan dokumen atau arsip negara.

Kutipan risalah lelang dalam pelaksanaan lelang melalui internet tidak sertamerta Kutipan Risalah lelang tersebut dapat diambil atau diunduh dengan leluasa dalam internet. Kutipan Risalah Lelang dengan pelaksanaan lelang melalui internet apabila ingin mendapatkan tetap harus datang di Kantor Pelayanan Kekayaan Negara dan Lelang (selanjutnya disebut KPKNL) yang menyelenggarakan lelang tersebut. Pada lampiran Peraturan Menteri Keuangan Nomor 90/PMK.06/2016 tentang Pedoman Pelaksanaan Lelang dengan Penawaran Secara Tertulis Tanpa Kehadiran Peserta Lelang Melalui Internet, menyatakan bahwa Kutipan Risalah Lelang diambil oleh Pembeli atau kuasanya di KPKNL yang menyelenggarakan lelang. Dengan demikian bahwa kutipan Risalah Lelang apabila ingin mengambilnya tetap harus datang ke KPKNL yang menyelenggarakan lelang. Tidak serta merta dapat diambil atau di unduh melalui internet. Peserta lelang atau pembeli tetap harus datang ke KPKNL. Pelaksanaan lelang melalui internet hanya sebatas pelaksanaannya dengan cara melalui internet namun kekuatan hukum dan pembuatan Risalah Lelang maupun Kutipan Risalah Lelang tetap sama seperti lelang secara konvensional.

Kekuatan hukum Risalah Lelang melalui internet tetap sama seperti kekuatan hukum pada lelang konvensional. Pada Peraturan Menteri Keuangan baik pelelangan dengan pelaksanaan melalui internet maupun dengan Pelaksanaan Lelang secara konvensional menyebutkan bahwa Risalah Lelang merupakan suatu Berita acara yang merupakan akta otentik dan mempunyai kekuatan pembuktian sempurna. Otentik dan mempunyai kekuatan pembuktian sempurna disini dilihat dari unsur otentik itu sendiri. Pada Pasal 1868 KUHPerdata menyatakan bahwa 
suatu akta otentik ialah suatu akta yang didalam bentuk yang ditentukan oleh undang-undang, dibuat oleh atau dihadapan pegawai-pegawai umum yang berkuasa untuk itu di tempat di mana akta dibuatnya.

\section{Pembuatan Akta Risalah Lelang Melalui Internet}

Peraturan Menteri Keuangan Nomor 90/PMK.06/2016 tentang Pedoman Pelaksanaan Lelang dengan Penawaran Secara Tertulis Tanpa Kehadiran Peserta Lelang Melalui Internet mengenai pembuatan akta risalah lelang tidak di tuliskan. Peraturan Menteri tersebut hanya menjelaskan mengenain pengertian risalah lelang, minuta risalah lelang dan bagaimana cara penandatanganan Minuta Risalah Lelang.

Pengaturan struktur bagian dalam akta risalah lelang terdapat dalam Peraturan Lelang Peraturan Penjualan di Muka Umum di Indonesia (Vendu Reglement) pada Pasal 37 menyatakan bahwa berita acara berisikan:

a. di bagian pokok:

b. di bagian batang tubuh;

c. pada bagian penutup.

Dalam Peraturan Menteri Keuangan Nomor 27/PMK.06/2016 tentang Petunjuk Pelaksanaan Lelang BAB VI mengenai risalah lelang juga mengatur susunan dari risalah lelang. Pasal 85 ayat (2) risalah lelang terdiri atas:
a. Bagian Kepala;
b. Bagian Badan; dan
c. Bagian Kaki

Risalah Lelang dibuat dalam bahasa Indonesia, setiap risalah lelang diberi nomor urut. Pasal 86 Peraturan Menteri Keuangan Nomor 27/PMK.06/2016 tentang Petunjuk Pelaksanaan Lelang, menerangkan bagian Kepala risalah lelang paling sedikit memuat: ${ }^{24}$

a. hari, tanggal, dan jam lelang ditulis dengan huruf dan angka;

b. nama lengkap dan tempat kedudukan Pejabat Lelang;

c. nomor dan tanggal surat keputusan pengangkatan Pejabat Lelang;

d. nomor dan tanggal surat tugas khusus untuk Pejabat Lelang Kelas I;

e. nama lengkap, pekerjaan dan tempat kedudukan atau domisili Penjual; Pasal 86

${ }^{24}$ Lihat Peraturan Menteri Keuangan Nomor 27/PMK.06/2016 tentang Petunjuk Pelaksanaan Lelang 

f. nomor atau tanggal surat permohonan lelang;
g. tempat pelaksanaan lelang;
h. sifat barang yang dilelang dan alasan barang tersebut dilelang;
i. dalam hal objek lelang berupa barang tidak bergerak berupa tanah atau tanah dan bangunan harus disebutkan;
j. dalam hal objek lelang berupa barang bergerak harus disebutkan jumlah, jenis dan spesifikasi barang;
k. cara Pengumuman Lelang yang telah dilaksanakan oleh Penjual;
1. cara penawaran lelang; dan
m.syarat dan ketentuan lelang.

\section{Bagian Badan Risalah Lelang paling kurang memuat: ${ }^{25}$}

a. banyaknya penawaran lelang yang masuk dan sah;

b. nama/merek/ jenis/tipe dan jumlah barang yang dilelang;

c. nama, pekerjaan dan alamat Pembeli atas nama sendiri atau sebagai kuasa atas nama badan hukum/badan usaha/ orang lain;

d. bank kreditor sebagai Pembeli untuk orang atau badan hukum atau badan usaha yang akan ditunjuk namanya, dalam hal bank kreditor sebagai Pembeli Lelang;

e. harga lelang dengan angka dan huruf; dan

f. daftar barang yang laku terjual maupun yang ditahan disertai dengan harga, nama, dan alamat Peserta Lelang yang menawar tertinggi.

\section{Bagian Kaki Risalah Lelang paling kurang memuat: ${ }^{26}$}

a. banyaknya barang yang ditawarkan ·atau dilelang dengan angka dan huruf;

b. banyaknya barang yang laku atau terjual dengan angka dan huruf;

c. jumlah harga barang yang telah terjual dengan angka dan huruf;

d. jumlah harga barang yang ditahan dengan angka dan huruf;

e. banyaknya dokumen atau surat-surat yang dilampirkan pada Risalah Lelang dengan angka dan huruf;

f. jumlah perubahan yang dilakukan (catatan, tambahan, coretan dengan penggantinya) maupun tidak adanya perubahan ditulis dengan angka dan huruf;

g. tanda tangan Pejabat Lelang dan Penjual atau kuasa Penjual, dalam hal lelang barang bergerak atau tanda tangan Pejabat Lelang, Penjual atau kuasa Penjual dan Pembeli atau kuasa Pembeli, dalam hal lelang barang tidak bergerak; dan

${ }^{25}$ Lihat Peraturan Menteri Keuangan Nomor 27/PMK.06/2016 tentang Petunjuk Pelaksanaan Lelang Pasal 87

${ }^{26}$ Lihat Peraturan Menteri Keuangan Nomor 27/PMK.06/2016 tentang Petunjuk Pelaksanaan Lelang 
h. tanda tangan saksi-saksi untuk lelang dengan penawaran tanpa kehadiran Peserta Lelang melalui surat elektronik (emai), tromol pos atau internet (closed bidding)

\section{Implementasi Pembuatan Risalah Lelang Melalui Internet}

Pelaksanaan pembuatan risalah lelang melalui internet dalam Peraturan Menteri Keuangan Nomor 90/PMK.06/2016 tentang Pedoman Pelaksanaan Lelang dengan Penawaran Secara Tertulis Tanpa Kehadiran Peserta Lelang Melalui Internet tidak diatur, dalam peraturan tersebut mengenai risalah lelang hanya mengatur sebatas penandatanganan risalah lelang.

Pelaksanaan dalam membuat akta risalah lelang melalui internet sama seperti pembuatan akta risalah lelang dengan pelaksanaan konvensional. Perbedaaannya hanya sebatas pada pelaksanaanya, jika konvensional langsung dengan tatap muka namun jika melalui internet maka tanpa kehadiran peserta lelang. Mengenai isi dan struktur akta dalam akta risalah lelang itu sendiri sama dari bagian pokok atau awal, bagian batang tubuh atau isi dan pada bagian penutup. ${ }^{27}$ Dari pemaparan tersebut pembuatan dan bentuk akta risalah lelang baik melalui internet maupun melalui internet sama.

Aturan dalam pembuatan akta risalah lelang melalui internet tetap tunduk pada Peraturan Lelang (Vendu Reglement) dan Peraturan Menteri Keuangan Nomor 27/PMK.06/2016 tentang Petunjuk Pelaksanaan Lelang. Dimana akta risalah lelang harus mengikuti struktur bagian yang telah di tentukan. Bagian yang harus sesuai dalam pembuatan akta risalah lelang harus terdiri dari bagian kepala, bagian badan dan bagian kaki.

Pembuatan akta risalah lelang melalui internet harus sesuai dengan wilayah kerja yang telah ditentukan. Pada Pasal 2 ayat (2) Peraturan Menteri Keuangan Nomor 90/PMK.06/2016 tentang Pedoman Pelaksanaan Lelang dengan Penawaran Secara Tertulis Tanpa Kehadiran Peserta Lelang Melalui Internet menyetakan bahwa Pelaksanaan lelang sebagaimana dimaksud pada ayat (1) hanya dapat dilakukan terhadap barang yang berada di dalam wilayah kerja

${ }^{27}$ Wawancara dengan Notaris-PPAT dan Pejabat Lelang Kelas II Kota Yogyakarta pada hari Kamis tanggal 18 Mei 2017 
KPKNL atau wilayah jabatan Pejabat Lelang Kelas II, sesuai dengan kewenangan masing-masing. Perlu dipahami bahwa pelaksanaan wilayah lelang dapat dilaksanakan apabila barang yang di lelang berada dalam wilayah kerja pejabat lelang itu sendiri.

Notaris tetap dapat membuat akta risalah lelang baik konvensional maupun melalui internet dengan catatan harus mengikuti seluruh aturan yang dibuat oleh Menteri Keuangan. Tidak serta merta notaris dapat membuat akta risalah lelang tanpa pengangkatan oleh Direktorat Jendral Kekayaan Negara dan memenuhi semua syarat yang telah ditentukan.

\section{Penutup}

Berdasarkan pembahasan dan analisis terhadap permasalahan, kesimpulan yang dapat diambil adalah sebagai berikut: Pertama, pada Pasal 15 UndangUndang Nomor 2 Tahun 2014 tentang Jabatan Notaris tidak serta-merta dapat diterapkan begitu saja. Artinya seorang Notaris tidak dapat langsung memangku jabatan sebagai pejabat lelang. Hal ini dikarenakan pengangkatan pejabat lelang dilakukan oleh Menteri Keuangan, sedangkan pengangkatan Notaris dilakukan oleh Menteri Hukum dan Hak Asasi Manusia. UUJN telah memberikan perluasan kewenangan kepada Notaris dalam menjalankan jabatanya sebagai pejabat umum. Salah satunya mengenai kewenangan yang terdapat dalam Pasal 15 ayat (2) huruf g, bahwa Notaris berwenang membuat akta risalah lelang namun peraturan tersebut tidak dapat diterapkan secara langsung tanpa adanya pengangkatan dari kementrian keuangan.

Kedua, kekuatan hukum Risalah Lelang melalui internet tetap sama seperti kekuatan hukum pada lelang konvensional. Pada Peraturan Menteri Keuangan baik pelelangan dengan pelaksanaan melalui internet maupun dengan Pelaksanaan Lelang secara konvensional menyebutkan bahwa Risalah Lelang merupakan suatu Berita acara yang merupakan akta otentik dan mempunyai kekuatan pembuktian sempurna. Pelaksanaan dan peraturan dalam membuat akta risalah lelang melalui internet sama seperti pembuatan akta risalah lelang dengan pelaksanaan konvensional. Perbedaaannya hanya sebatas pada pelaksanaanya, jika 
konvensional langsung dengan tatap muka namun jika melalui internet maka tanpa kehadiran peserta lelang. Peraturan kedua pelaksanaan lelang tersebut diatur dalam Peraturan Lelang Peraturan Penjualan di Muka Umum di Indonesia (Vendu Reglement) pada Pasal 37 dan pada Peraturan Menteri Keuangan Nomor 27/PMK.06/2016 tentang Petunjuk Pelaksanaan Lelang BAB VI mengenai Risalah lelang. Sedangkan apabila pembeli atau kuasanya ingin mengambil kutipan risalah lelang tetap diambil di KPKNL yang menyelenggarakan lelang hal ini diatur pada lampiran Peraturan Menteri Keuangan Nomor 90/PMK.06/2016 tentang Pedoman Pelaksanaan Lelang dengan Penawaran Secara Tertulis Tanpa Kehadiran Peserta Lelang Melalui Internet.

Adapun saran yang dapat diberikan adalah sebagai berikut: Satu, perlu di buat dan di undangkan Undang-Undang baru yang mengatur tentang Lelang dan Pejabat Lelang di Indonesia lengkap dengan aturan mengenai pelaksanaan serta pengawasannya. Dua, perlu pengedukasian kepada masyarakat mengenai penjualan dimuka umum atau pelelangan baik pelaksanaan lelang konvensional maupun pelaksanaan lelang melalui internet, pejabat lelang dalam praktiknya banyak yang tidak melaksanakan lelang karna minimnya dalam pengajuan jualbeli melalui lelang. Tiga, perlu diadakan sosialisasi mengenai aturan dan fasilitas baru terhadap pejabat lelang, balai lelang maupun masyarakat tentang pelaksanaan lelang melalui internet, dimana hal tersebut penting untuk kemajuan penjualan dimuka umum atau lelang mealui internet agar lebih efisien dalam penggunaanya.

\section{Daftar Pustaka}

\section{Buku}

Abdul Ghofur Anshori, Lembaga Kenotariatan Indonesia Perpektif Hukum dan Etika, Tim UII Press, Yogyakarta, 2009.

G.H.S Lumban Tobing, Peraturan Jabatan Notaris, Erlangga, Jakarta, 1983.

Habib Adjie, Hukum Notaris Indonesia, PT. Refika Aditama, Bandung, 2008.

Mukti Fajar dan Yulianto Ahmad, Dualisme Penelitian Hukum, Normatif dan Empiris, Pustaka Prima, Yogyakarta, 2015.

Peter Mahmud Marzuki, Penelitian Hukum, Edisi Revisi, Cetakan ke-9, Kencana, Jakarta, 2014. 
Rachmadi Usman, Hukum Lelang, Sinar Grafika Offset, Jakarta, 2016.

Sjaifurrachman \& Habib Ajie, Aspek Pertanggungjawaban Notaris dalam Pembuatan Akta, CV. Mandar Maju, Bandung, 2011.

\section{Peraturan Perundang-undangan}

Kitab Undang-Undang Hukum Perdata

Undang-Undang No 2 Tahun 2014 tentang Pengganti Undang-Undang nomor 32 Tahun 2004 tentang Jabatan Notaris

Peraturan Lelang (Vendu Reglement)

Peraturan Menteri Keuangan Nomor 27/PMK.06/2016 tentang Petunjuk Pelaksanaan Lelang.

Peraturan Menteri Keuangan Nomor 90/PMK.06/2016 tentang Pedoman Pelaksanaan Lelang dengan Penawaran Secara Tertulis Tanpa Kehadiran Peserta Lelang melalui Internet

Peraturan Menteri Keuangan Nomor 175/PMK.06/2010 tentang Pejabat Lelang Kelas II sebagaimana telah diubah dengan PMK Nomor 159/PMK.06/2013 